\title{
PERSAMAAN EMPIRIS WAKTU GETAR ALAMI STRUKTUR PELAT DATAR BETON BERTULANG BERDASARKAN HASIL ANALISIS VIBRASI 3 DIMENSI
}

\section{Empirical Formula for Fundamental Period of Flate Plate Reinforced Concrete Structure Based on 3 Dimentional Vibration Analysis}

\author{
Agus Setiawan \\ Jurusan Teknik Sipil, Fakultas Teknik,Universitas Pembangunan Jaya \\ Alamat Korespondensi : BJl. Cendrawasi, Ciputat, Sawah Baru, Tangerangan Selatan, Banten 15413 \\ Email : agustinus@upj.ac.id
}

\begin{abstract}
One of the parameters required in the calculation of seismic base shear on a structure is the fundamental period of the structure. The fundamental period of structure can be obtained through three-dimensional dynamic analysis of the structure. Indonesian Standard Code for Earthquake Resistance Building, SNI 1726-2012, given some empirical equations to calculate the fundamental period ofsome structural system. Some of the given equation can be used for concrete and steel frame structure. However, for the flat plate reinforced concrete structure, sometimes the fundamental period approached as "other structural systems", which of course can not be shown for accuracy. This study was conducted to obtain an empirical equation that can be used to calculate the fundamental periodof a flat plate structure. The flat plate reinforced concrete structure model being analyzed is vary in total floor number, which varies from 1 to 10 floors, and the width of the building from 20 to 28 meters. From the analysis results obtained relationship between fundamental period, building width and building height in the form $T_{a}=0,0022(B)^{\prime}$ ' $h_{n}^{1,15}$, for the un-cracked section. And $T_{a}=$ $0,0025(B)^{\prime}$ '" $h_{n}^{1,28}$, for the condition of cracked cross-section, with $T_{n}$ is fundamental period, $B$ is the width of the building plan, and $h_{n}$ is the height of the building.
\end{abstract}

Keywords : Time Period, Flat Plate, Reinforced Concrete

\begin{abstract}
Abstrak
Salah satu parameter yang diperlukan dalam perhitungan gaya geser dasar seismik pada suatu struktur adalah besarnya waktu getar alami dari struktur tersebut. Nilai waktu getar alami struktur dapat diperoleh melalui hasil analisis dinamik 3 dimensi dari struktur tersebut. Namun dalam Standar Perencanaan Ketahanan Gempa SNI 1726-2012, juga diberikan beberapa persamaan empiris untuk menghitung waktu getar alami struktur. Beberapa persamaan yang diberikan dapat digunakan untuk sistem struktur rangka beton dan baja. Namun untuk sistem struktur berupa pelat datar (flat plate) beton bertulang, terkadang nilai waktu getarnya didekati sebagai "sistem struktur lainnya", yang tentu saja tidak dapat ditunjukkan keakuratannya. Penelitian ini dilakukan dengan tujuan untuk mendapatkan persamaan empiris yang dapat digunakan untuk menghitung waktu getar alami suatu struktur pelat datar. Model yang dianalisis berupa struktur pelat datar beton bertulang, dengan jumlah lantai bervariasi dari 1 hingga 10 lantai, serta lebar bangunan dari 20 hingga 28 meter. Dari hasil analisis diperoleh hubungan waktu getar alami dengan lebar bangunan dan tinggi bangunan dalam bentuk $\mathrm{T}_{\mathrm{a}}$ $=0,0022(\mathrm{~B}){ }^{\prime}{ }^{\prime} \mathrm{h}_{\mathrm{n}}^{1,15}$, untuk kondisi penampang utuh. Serta $\mathrm{T}_{\mathrm{a}}=0,0025(\mathrm{~B}){ }^{\prime} \mathrm{h}_{\mathrm{n}} \mathrm{h}^{1,28}$, untuk kondisi penampang retak, dengan $T_{n}$ adalah waktu getar alami, $B$ adalah lebar denah bangunan, serta $h_{n}$ adalah tinggi bangunan.
\end{abstract}

Kata kunci : Waktu Getar Alami, Pelat Datar, Beton Bertulang

\section{PENDAHULUAN}

Waktu getar alami suatu struktur bangunan merupakan parameter yang cukup penting dalam proses desain suatu struktur bangunan. Dalam perencanaan struktur bangunan tahan gempa, maka informasi awal mengenai waktu getar alami struktur bangunan tersebut sangat dibutuhkan untuk menghitung gaya geser dasar seismik yang bekerja. Waktu getar alami suatu struktur bangunan gedung 
dapat ditentukan menggunakan persamaanpersamaan empiris, maupun dapat pula ditentukan melalui suatu prosedur analisis dinamis melalui bantuan piranti lunak yang tersedia. Persamaanpersamaan empiris untuk menentukan waktu getar alami bangunan pada umumnya tercantum dalam peraturan perencanaan struktur yang berlaku di suatu negara. Dalam SNI 1726-2012 mengenai "Standar Perencanaan Ketahanan GempaUntuk Struktur Bangunan GedungDan Non Gedung" dicantumkan pula rumus empiris yang dapat digunakan untuk menentukan periode alami suatu struktur bangunan.Namun demikian rumus empiris untuk penentuan waktu getar alami yang dicantumkan dalam SNI 1726-2012 tidak dapat mewakili kesemua jenis atau tipe struktur yang ada. Rumus empiris yang dicantumkan terbatas untuk jenis struktur rangka baja/beton pemikul momen, serta jenis struktur rangka baja dengan bracing. Selain dalam kategori jenis struktur tersebut, SNI 1726-2012 memberikan jenis struktur yang diklasifikasikan sebagai "sistem struktur lainnya". Tentunya pendekatan ini terkadang akan memberikan hasil yang kurang memuaskan bagi sistem struktur tertentu.Balkaya\& Kalkan (2003) menemukan bahwa persaman empiris untuk perhitungan waktu getar tidak akurat untuk diterapkan pada struktur bangunan yang didominasi oleh dinding geser. Abdo (2012) menganalisis sistem plat datar yang dikombinasi dengan dinding geser juga menemukan ketidak akuratan pada perhitungan waktu getar menggunakan persamaan empiris. Sedangkan Cinitha et.al. (2012) menemukan ketidakakuratan persamaan empiris pada bangunan rangka baja dengan ketinggian sedang dan rendah.

Sistem plat datar (flat plate) dan sistem slab datar (flat slab)merupakan jenis struktur yang tidak dapat dikategorikan sebagai struktur rangka beton. Sehingga dalam penentuan waktu getar alaminya, kedua jenis struktur ini dapat dikategorikan sebagai "sistem struktur lainnya" menurut SNI 1726-2012. Namun pendekatan ini tentunya tidaklah memuaskan karena kedua jenis sistem struktur ini menunjukkan perilaku yang lebih lentur/fleksibel dibandingkan struktur balok-kolom ataupun struktur dengan dinding geser (Abdo, 2012). Sistem struktur plat datar memberikan beberapa keuntungan dalam penggunaannya, seperti mampu mengurangi tinggi bangunan, memberikan jarak yang cukup antar lantai, serta kemudahan dalam pelaksanaannya. Namun kekurangan sistem struktur plat datar ini adalah bahwa kekakuannya dalam arah lateral yang cukup lemah karena ketiadaan balok maupun dinding geser. Hal ini akan cukup menimbulkan resiko kerusakan apabila struktur tersebut dikenai beban gempa. Oleh karena itu penentuan waktu getar alami bagi suatu sistem plat datar akan menjadi hal yang sangat penting, karena waktu getar ini akan menentukan berapa besar gaya gempa yang harus dipikul oleh sistem struktur plat datar ini.

Studi ini bertujuan untuk membandingkan waktu getar alami suatu sistem struktur plat datar (flat plate) yang diperoleh dari hasil perhitungan menggunakan rumus empiris dengan hasil analisis getaran bebas 3 dimensi yang dihitung oleh piranti lunak ETABS versi 9.0. Model struktur plat datar yang akan dihitung waktu getarnya terdiri dari bangunan 1hingga 10 lantai. Model struktur berdasarkan denahnya dibedakan menjadi tiga macam, yaitu struktur dengan lebar 20 m, 24 m dam $28 \mathrm{~m}$.

\section{METODE PENELITIAN}

\section{Periode Alami Berdasarkan Analisis Dinamik}

Waktu getar alami suatu struktur diperoleh dari hasil analisis getaran bebas tanpa redaman. Untuk suatu sistem struktur yang memiliki derajat kebebasan (Degree of Freedom, DoF) lebih dari satu, atau dinamakan Multi Degree of Freedom (MDoF), persamaan gerak akibat getaran bebasnya dapat dituliskan sebagai berikut :

$$
[m]\{\ddot{x}\}+[k]\{x\}=0
$$

Salah satu solusi dari persamaan (1) adalah :

$$
\{x\}=\{A\} \sin \omega t
$$

Derivatif pertama dan kedua dari persamaan (2) secara berturutan adalah :

$$
\left\{\begin{array}{l}
\dot{x}\}=\{A\} \omega \cos \omega t(3) \\
\ddot{x}\}=-\{A\} \omega^{2} \sin \omega t
\end{array}\right.
$$

Dengan substitusi persamaan (2) dan (4) ke dalam persamaan (1), maka akan diperoleh : 


$$
\left\{-\omega_{n}{ }^{2}[m]+[k]\right\}\{A\} \sin \omega_{n}=\{0\}(5) \quad T_{1}=\frac{2 \pi}{\omega_{1}}
$$

Untuk $\{A\}^{1} 0$, maka solusi non trivialdari persamaan (5) diperoleh dari syarat determinan :

$$
\mid K]-\omega_{n}^{2}[M] \mid=0(6)
$$

Persamaan determinan ini akan menghasilkan " $n$ " buah $\mathrm{w}_{n}$ yang disebut dengan istilah "eigen values" di mana jumlah $n=$ jumlah degree of freedom. Parameter ? dalam analisis dinamik struktur dikenal sebagai frekuensi alami struktur. Nilai tertinggi dari ? ${ }_{n}$ didefinisikan sebagai ? ${ }_{1}$, yang mempunyai korelasi dengan waktu getar alami struktur, $T_{1}$ yaitu : sebagai berikut :

$$
T_{a} \quad=C_{t} h_{n}^{x}
$$
1.

\section{Periode Alami Berdasarkan SNI 1726-2012}

SNI 1726-2012 menentukan persamaan empirik yang dapat digunakan untuk menghitung periode alami dari suatu struktur bangunan, $T_{a}$,

dengan $h_{n}$ adalah ketinggian struktur (dalam meter) di atas dasar sampai tingkat tertinggi struktur, sedangkan koefisien $C_{t}$ dan $x$ ditentukan dari Tabel

Tabel 1. Nilai Parameter Periode Pendekatan $C_{t}$ dan $x$

\begin{tabular}{lcc}
\hline \multicolumn{1}{c}{ Tipe Struktur } & $C_{t}$ & $x$ \\
\hline $\begin{array}{l}\text { Sistem rangka pemikul momen dimana rangka memikul 100\% gaya seismik yang } \\
\text { disyaratkan dan tidak dilingkupi atau dihubungkan dengan komponen yang lebih kaku } \\
\text { dan akan mencegah rangka dari defleksi jika dikenai gaya gempa : }\end{array}$ & & \\
& & \\
Rangka baja pemikul momen & 0,0724 & 0,80 \\
Rangka beton pemikul momen & 0,0466 & 0,90 \\
Rangka baja dengan bracing eksentris & 0,0731 & 0,75 \\
Rangka baja dengan bracing terkekang terhadap tekuk & 0,0731 & 0,75 \\
Semua sistem struktur lainnya & 0,0488 & 0,75 \\
\hline
\end{tabular}

Sedangkan untuk struktur dengan ketinggian tidak melebihi 12 tingkat serta sistem penahan gaya gempa berupa rangka penahan momen beton dan tinggi tingkat paling sedikit $3 \mathrm{~m}$, maka periode alami pendekatan, $T_{a}$, dapat dihitung dengan persamaan berikut :

$$
T_{a} \quad=0,1 N
$$

dengan $N$ adalah jumlah tingkat.

Periode alami struktur, $T$, dalam arah yang ditinjau tidak boleh melebihi hasil kali koefisien untuk batasan atas pada periode yang dihitung $\left(C_{u}\right)$ dari Tabel 2 dan periode alami pendekatan, $T_{a}$, yang dihitung berdasarkan persamaan (1) atau (2).
Tabel 2.Koefisien Untuk Batas Atas Pada Periode Yang Dihitung

\begin{tabular}{cc}
\hline $\begin{array}{c}\text { Parameter Percepatan } \\
\text { Respons Spektral } \\
\text { Desain pada 1 detik, }\end{array}$ & $\begin{array}{c}\text { Koefisien } \\
C_{U}\end{array}$ \\
\hline$S_{D 1}$ & \\
\hline$\geq 0,4$ & 1,4 \\
0,3 & 1,4 \\
0,2 & 1,5 \\
0,15 & 1,6 \\
$\leq 0,1$ & 1,7 \\
\hline
\end{tabular}

\section{Deskripsi Model Struktur Bangunan}

Model struktur bangunan yang dianalisis adalah merupakan struktur beton bertulang dengan jenis lantai struktur berupa sistem plat datar (flat plate) tanpa balok tepi dan balok dalam. Model yang dianalisis ada 3 macam yang dibedakan berdasarkan ukuran denah. Model pertama memiliki denah lantai 
berbentuk bujur sangkar, dengan ukuran panjang dalam arah $x$ dan $y$ masing - masing adalah 20,00 $\mathrm{m}$, yang terbagi menjadi 4 bentangan, sehingga panjang bentang pelat dikur dari as ke as kolom adalah sepanjang 5,00 m pada kedua arah. Model pertama ditunjukkan dalam Gambar 1 .

Model kedua memiliki denah lantai berbentuk bujur sangkar, dengan ukuran panjang dalam arah $x$ dan $y$ masing - masing adalah $24,00 \mathrm{~m}$, yang terbagi menjadi 4 bentangan, sehingga panjang bentang pelat dikur dari as ke as kolom adalah sepanjang 6,00 m pada kedua arah. Model kedua ditunjukkan dalam Gambar 2. Model ketiga memiliki denah lantai berbentuk bujur sangkar, dengan ukuran panjang dalam arah $x$ dan $y$ masing - masing adalah 28,00 $\mathrm{m}$, yang terbagi menjadi 4 bentangan, sehingga panjang bentang pelat dikur dari as ke as kolom adalah sepanjang 7,00 m pada kedua arah. Model ketiga ditunjukkan dalam Gambar 3.

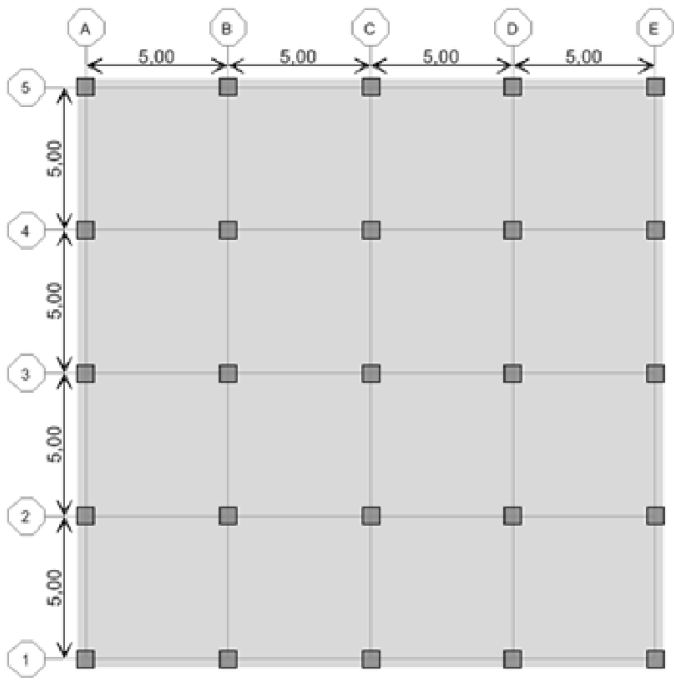

Gambar 1. Denah Lantai Tipikal Model 1.

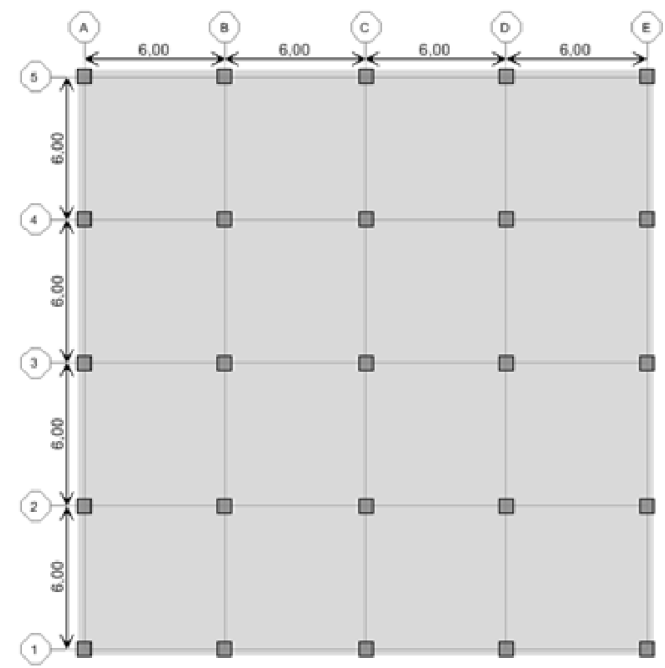

Gambar 2. Denah Lantai Tipikal Model 1.

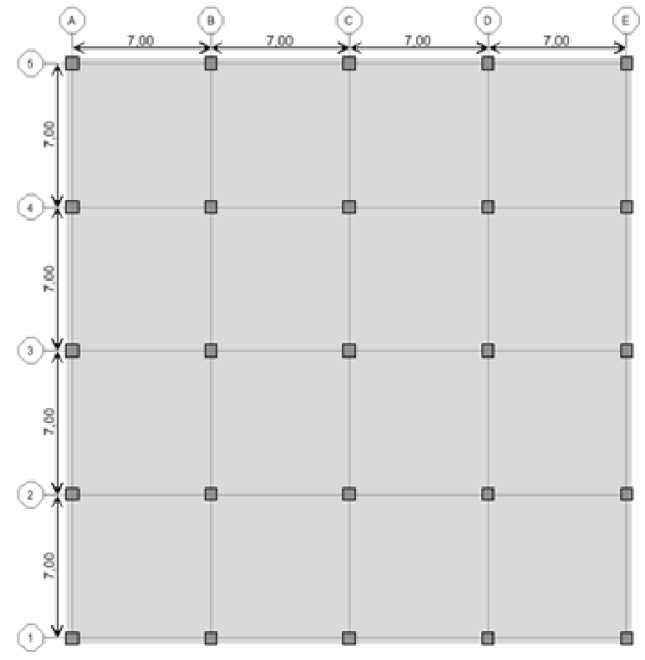

Gambar 3. Denah Lantai Tipikal Model 3.

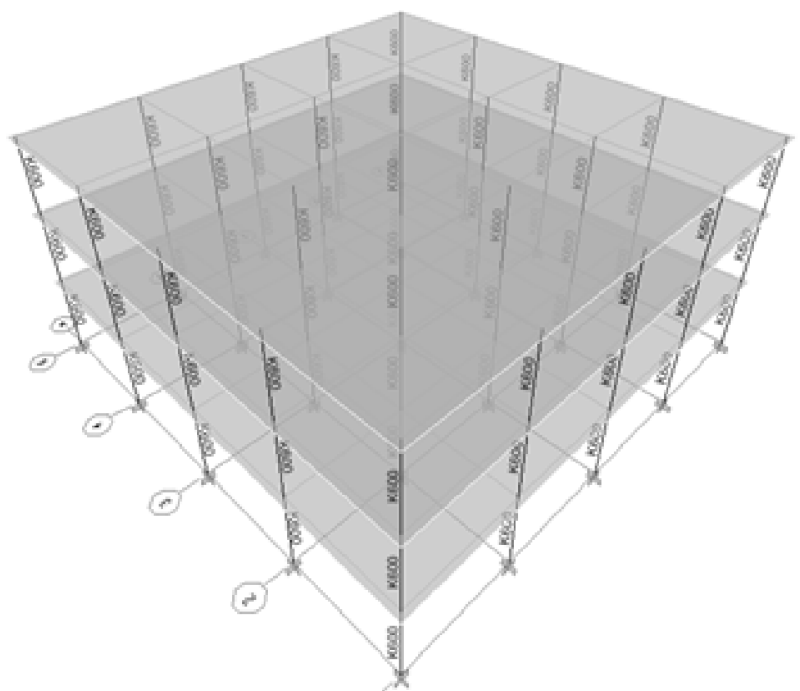

Gambar 4. Tampilan Model 3 Dimensi.

Kolom yang digunakan berukuran seragam yaitu $600 \times 600 \mathrm{~mm}^{2}$. Mutu beton yang digunakan adal ah $f_{c}^{\prime}=30 \mathrm{MPa}$, dengan mutu baja tulangan $f_{y}$ $=400 \mathrm{MPa}$. Modulus Elastisitas beton diambil sebesar, $E=4.700 " f_{c}^{\prime}=25.700 \mathrm{MPa}$. Masing-masing model dibuat dengan jumlah lantai bervariasi dari 1 hingga 10 lantai.Tinggi lantai ke lantai seragam sebesar 3,50 m. Tumpuan dimodelkan sebagai tumpuan jepit, dan lantai dianggap sebagai diafragma kaku (rigid diaphragm).

Ketebalan pelat ditentukan berdasarkan persyaratan ketebalan minimum pelat yang diatur dalam SNI 2847:2013 pasal 9.5.3.3. Ketentuan mengenai tebal minimum pelat ditunjukkan dalam Tabel 3 sebagai berikut. 
Tabel 3.Tebal Minimum Pelat Tanpa Balok Dalam

\begin{tabular}{|c|c|c|c|c|c|c|}
\hline \multirow{3}{*}{$\begin{array}{c}f_{y} \\
(\mathrm{MPa})\end{array}$} & \multicolumn{3}{|c|}{ Tanpa Penebalan Panel } & \multicolumn{3}{|c|}{ Dengan Penebalan Panel } \\
\hline & \multicolumn{2}{|c|}{ Panel Luar } & \multirow[b]{2}{*}{$\begin{array}{l}\text { Panel } \\
\text { Dalam }\end{array}$} & \multicolumn{2}{|c|}{ Panel Luar } & \multirow{2}{*}{$\begin{array}{c}\text { Panel } \\
\text { Dalam }\end{array}$} \\
\hline & $\begin{array}{c}\text { Tanpa } \\
\text { Balok Tepi }\end{array}$ & $\begin{array}{c}\text { Dengan } \\
\text { Balok Tepi }\end{array}$ & & $\begin{array}{c}\text { Tanpa } \\
\text { Balok Tepi }\end{array}$ & $\begin{array}{c}\text { Dengan } \\
\text { Balok Tepi }\end{array}$ & \\
\hline 280 & $l_{n} / 33$ & $l_{n} / 36$ & $l_{n} / 36$ & $l_{n} / 36$ & $l_{n} / 40$ & $l_{n} / 40$ \\
\hline 420 & $l_{n} / 30$ & $l_{n} / 33$ & $l_{n} / 33$ & $l_{n} / 33$ & $l_{n} / 36$ & $l_{n} / 36$ \\
\hline 520 & $l_{n} / 28$ & $l_{n} / 31$ & $l_{n} / 31$ & $l_{n} / 31$ & $l_{n} / 34$ & $l_{n} / 34$ \\
\hline
\end{tabular}

Berdasarkan ketentuan dalam Tabel 3 tersebut, maka ketebalan minimum yang dianjurkan untuk sistem struktur plat datar tanpa balok tepi adalah sebesar $l_{n} / 33$ untuk panel dalam, dan $l_{n} / 30$ untuk panel luar.Nilai $l_{n}$ adalah panjang bentang bersih pelat, dalam studi ini, maka panjang bentang bersih pelat adalah sebesar $l_{n}=6.000-600 \mathrm{~mm}=5.400$ $\mathrm{mm}$.Sehingga untuk panel dalam dibutuhkan tebal minimum pelat sebesar 5.400/33 $=164 \mathrm{~mm}$, dan untuk panel luar dibutuhkan tebal minimum 5.400/ $30=180 \mathrm{~mm}$. Untuk keperluan analisis maka ketebalan pelat diambil seragam setebal $200 \mathrm{~mm}$.

\section{Perhitungan Beban}

Beban yang diberikan pada lantai terdiri dari beban mati dan beban hidup, yang diperhitungkan sebagai berikut :

Beban Mati :

Berat sendiri pelat $=0,20 \times 2.400=480 \mathrm{~kg} / \mathrm{m}^{2}$

(sudah dihitung dalam program)

Beban mati tambahan yang berupa :

- $\quad$ Berat screed dan penutup lantai $=0,3 \times 2.400$ $=720 \mathrm{~kg} / \mathrm{m}^{2}$

- $\quad$ Berat plafond dan penggantung $=11+1=18$ $\mathrm{kg} / \mathrm{m}^{2}$

- Beban plumbing dan M.E $=50 \mathrm{~kg} / \mathrm{m}^{2}$ (asumsi)

Total beban mati tambahan $\quad=788 \mathrm{~kg} / \mathrm{m}^{2}$

Beban Hidup untuk fungsi hunian $=250 \mathrm{~kg} / \mathrm{m}^{2}$

Untuk perhitungan waktu getar alami maka dibutuhkan input sumber massa. Dalam SNI 17262012 "Standar Perencanaan Ketahanan Gempa Untuk Struktur Bangunan Gedung dan Non Gedung", ditentukan bahwa berat seismik efektif struktur, $W$, harus menyertakan seluruh beban mati dan beban lainnya yaitu :

- Dalam daerah yang digunakan untuk penyimpanan: minimum sebesar 25 persen beban hidup lantai (beban hidup lantai di garasi publik dan struktur parkiran terbuka, serta beban penyimpanan yang tidak melebihi 5 persen dari berat seismik efektif pada suatu lantai, tidak perlu disertakan).

- Jika ketentuan untuk partisi disyaratkan dalam disain beban lantai: diambil sebagai yang terbesar di antara berat partisi aktual atau berat daerah lantai minimum sebesar $0,48 \mathrm{kN} / \mathrm{m}^{2}$.

- Berat operasional total dari peralatan yang permanen.

- Berat lansekap dan beban lainnya pada taman atap dan luasan sejenis lainnya.

Sehingga dari ketentuan tersebut, sumber massa (mass source) bangunan diperbolehkan diambil hanya berasal dari beban mati saja.

\section{Kekakuan Struktur}

Dalam perhitungan waktu getar alami struktur gedung, pengaruh peretakan beton pada unsur-unsur struktur dari beton bertulang, beton pratekan dan baja komposit diperhitungkan terhadap kekakuannya. Sesuai SNI 2847: 2013 momen inersia penampang unsur struktur dapat ditentukan sebesar momen inersia penampang utuh dikalikan dengan suatu persentase efektifitas penampang sebagai berikut :

Balok : $0,35 I_{g}$

Kolom : 0,70 $I_{g}$

Dinding : tidak retak : 0,70 $I_{g}$ : retak: 0,35 $I_{g}$ Pelat datar (flat plate) dan slab datar (flat slab) : $0,25 I_{g}$

Luas : $1,0 I_{g}$ (Lihat Peraturan Beton SNI 2847:2013 Pasal 10.10.4.1)

Perhitungan waktu getar alami dilakukan dengan mempertimbangkan dua macam kondisi penampang, yaitu kondisi penampang utuh serta kondisi penampang retak. 


\section{HASIL DAN PEMBAHASAN}

Analisis getaran bebas 3 dimensi untuk mendapatkan waktu getar alami struktur dilakukan dengan bantuan program ETABS v.9.0. Waktu getar alami yang diperoleh untuk ketiga model ditunjukkan dalam Tabel 4. Analisis dilakukan dengan mempertimbangan kondisi penampang struktur yang utuh, serta penampang dalam kondisi retak.

Nilai $T_{\text {empiris }}$ diperoleh dengan menggunakan persamaan (2), karena struktur gedung memiliki jumlah lantai sebanyak 10 . Nilai $T$ yang diperoleh dari persamaan (2) dikalikan dengan koefisien $C_{u}$, yang dalam kasus ini diambil sebesar 1,4.

Tabel 4. Hasil Analisis Dinamik Waktu Getar Alami

\begin{tabular}{cccccccccc}
\hline \multirow{2}{*}{$\begin{array}{c}\text { Jumlah } \\
\text { Lantai }\end{array}$} & $\begin{array}{c}\text { Tinggi } \\
(\mathrm{m})\end{array}$ & \multicolumn{2}{c}{$T_{\text {empiris }}$} & \multicolumn{2}{c}{$T_{\text {dinamik model 1 }}$} & \multicolumn{2}{c}{$T_{\text {dinamik model 2 }}$} & \multicolumn{2}{c}{$T_{\text {dinamik model 3 }}$} \\
& & Pers. (2) & $C_{u} \cdot T_{a}$ & $T_{d \text { retak }}$ & $T_{d \text { utuh }}$ & $T_{d \text { retak }}$ & $T_{d \text { utuh }}$ & $T_{d \text { retak }}$ & $T_{d \text { utuh }}$ \\
\hline 1 & 4 & 0,1 & 0,140 & 0,290 & 0,218 & 0,340 & 0,257 & 0,405 & 0,306 \\
2 & 8 & 0,2 & 0,280 & 0,738 & 0,496 & 0,854 & 0,566 & 1,036 & 0,700 \\
3 & 12 & 0,3 & 0,420 & 1,268 & 0,802 & 1,453 & 0,900 & 1,784 & 1,132 \\
4 & 16 & 0,4 & 0,560 & 1,838 & 1,123 & 2,094 & 1,248 & 2,588 & 1,583 \\
5 & 20 & 0,5 & 0,700 & 2,433 & 1,453 & 2,761 & 1,604 & 3,426 & 2,048 \\
6 & 24 & 0,6 & 0,840 & 3,046 & 1,790 & 3,448 & 1,966 & 4,290 & 2,521 \\
7 & 28 & 0,7 & 0,980 & 3,674 & 2,131 & 4,149 & 2,331 & 5,174 & 3,000 \\
8 & 32 & 0,8 & 1,120 & 4,313 & 2,475 & 4,862 & 2,698 & 6,073 & 3,482 \\
9 & 36 & 0,9 & 1,260 & 4,960 & 2,820 & 5,583 & 3,066 & 6,984 & 3,967 \\
10 & 40 & 1 & 1,400 & 5,613 & 3,168 & 6,310 & 3,545 & 7,904 & 4,453 \\
\hline
\end{tabular}

Hubungan antara tinggi bangunan $(h)$ dan waktu getar alami $(T)$ untuk masing-masing model ditampilkan dalam Gambar 5, 6 dan 7.

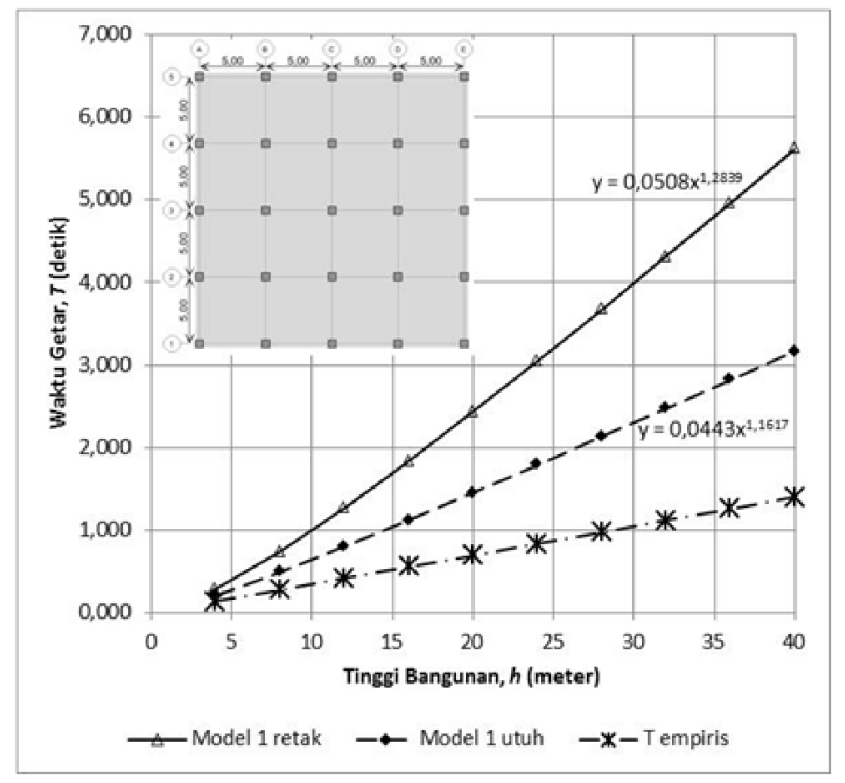

Gambar 5. Hubungan $h_{n}$ vs $T$ Model 1.

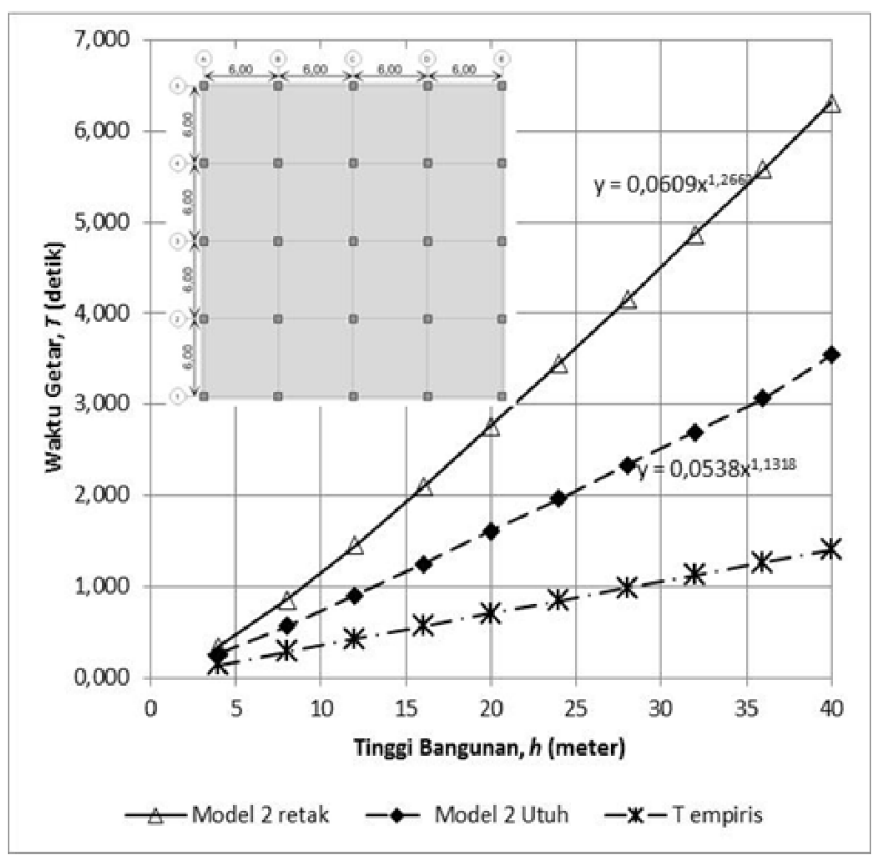

Gambar 6. Hubungan $h_{n}$ vs $T$ Model 2. 


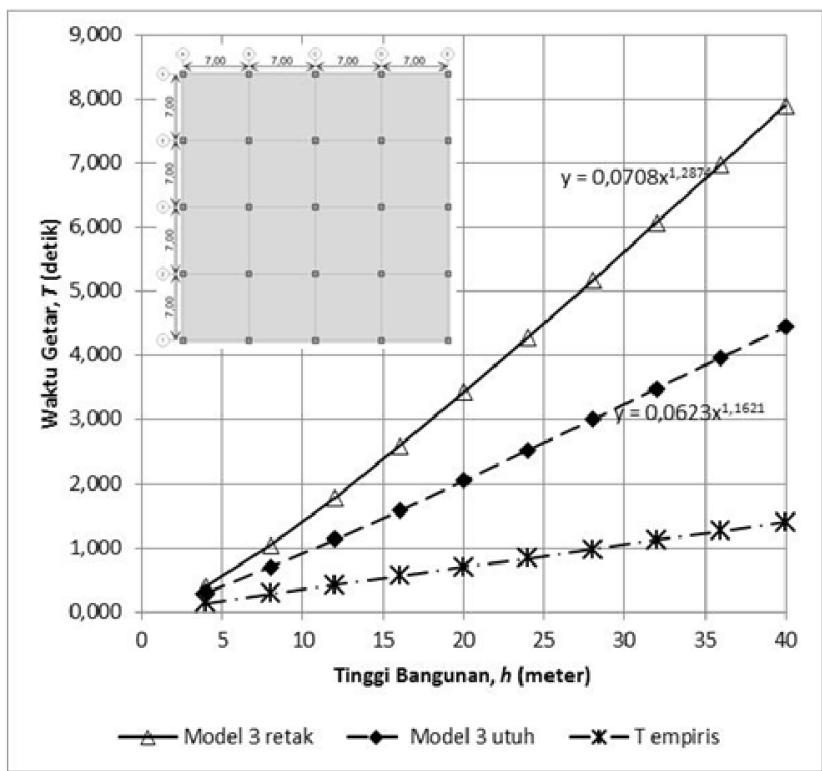

Gambar 7. Hubungan $h_{n}$ vs $T$ Model 3.

Dari hasil grafik yang ditunjukkan dalam Gambar 5,6, dan 7 nampak bahwa persaman empiris yang diberikan dalam SNI 1726-2012 cukup jauh dari waktu getar alami yang dihasilkan dari analisis dinamik. Oleh karena itu perlu diturunkan persamaan empiris yang dapat mewakili perhitungan waktu getar bangunan untuk struktur pelat datar (flat plate), agar dapat dihasilkan gaya geser dasar seismik yang tepat untuk digunakan dalam perhitungan beban gempa bangunan.

Untuk mendapatkan hubungan antara tinggi bangunan dan waktu getar alami, dilakukan analisis regresi dengan mengambil bentuk fungsi berpangkat sebagai berikut :

$T=\mathrm{a} . h^{\mathrm{b}}$

Dengan menggunakan fasilitas analisis regresi yang terdapat dalam $M S$-Excell diperoleh hubungan seperti ditunjukkan dalam Tabel 5.

Tabel 5. Analisis Regresi Antara Waktu Getar dan Tinggi Bangunan

\begin{tabular}{cccc}
\hline Model & Lebar, $B(\mathrm{~m})$ & Penampang Utuh & Penampang Retak \\
\hline Model 1 & 20 & $T=0,0443 . h^{1,1617}$ & $T=0,0508 \cdot h^{1,2839}$ \\
Model 2 & 24 & $T=0,0538 \cdot h^{1,1318}$ & $T=0,0609 \cdot h^{1,2662}$ \\
Model 3 & 28 & $T=0,0623 \cdot h^{1,1621}$ & $T=0,0708 \cdot h^{1,2874}$ \\
\hline
\end{tabular}

Selanjutnya persamaan hasil analisis regresi

$$
T_{a}=C_{t} h_{n}^{x}
$$

dapat dibuat lebih umum, sehingga dapat dipergunakan untuk berbagai kondisi denah bangunan. Persamaan empiris yang dihasilkan berupa persamaan eksponen, yang mempunyai bentuk seperti persamaan (1).

Tabel 6 menunjukkan koefisien $C_{t}$ serta eksponen $x$ dari model 1 hingga 3, untuk kondisi penampang utuh. Koefisien $C_{t}$ selanjutnya dapat dinyatakan sebagai fungsi dari lebar bangunan, $B$.

Tabel 6. Koefisien $C_{t}$ dan Eksponen $x$ Untuk Kondisi Penampang Utuh

\begin{tabular}{cccccc}
\hline Model & Lebar, $B(\mathrm{~m})$ & $C_{t}$ & $C_{t}(B)$ & $x$ & $x_{\text {rerata }}$ \\
\hline Model 1 & 20 & 0,0443 & & 1,1617 & \\
Model 2 & 24 & 0,0538 & $0,0022(B)$ & 1,1318 & 1,15 \\
Model 3 & 28 & 0,0623 & & 1,1621 & \\
\hline
\end{tabular}

Dari hasil analisis dalam Tabel 6, maka dapat diturunkan persamaan empiris untuk menghitung waktu getar dari struktur pelat datar (flat plate) untuk kondisi penampang utuh, yaitu :

$$
T_{a}=0,0022(B)^{\prime \prime} h_{n}^{1,15}
$$

Nilai $C_{t}$ dan $x$ untuk kondisi penampang retak, ditunjukkan dalam Tabel 7.

Tabel 7. Koefisien $C_{t}$ dan Eksponen $x$ Untuk Kondisi Penampang Utuh

\begin{tabular}{cccccc}
\hline Model & Lebar, $B(\mathrm{~m})$ & $C_{t}$ & $C_{t}(B)$ & $x$ & $x_{\text {rerata }}$ \\
\hline Model 1 & 20 & 0,0508 & & 1,2839 & \\
Model 2 & 24 & 0,0609 & $0,0025(B)$ & 1,2662 & 1,28 \\
Model 3 & 28 & 0,0708 & & 1,2874 & \\
\hline
\end{tabular}

Dari hasil analisis dalam Tabel 7, maka dapat diturunkan persamaan empiris untuk menghitung waktu getar dari struktur pelat datar (flat plate) untuk kondisi penampang retak, yaitu : 


$$
T_{a}=0,0025(B), " h_{n}^{1,28}
$$

Nilai waktu getar alami yang dihitung dari rumus empiris dalam persamaan (4) dan (5) dapat dikalikan dengankoefisien batas atas, $C_{u}$, dari Tabel 2. Dalam suatu perencanaan struktur, hasil analisis dinamik 3 dimensi dengan menggunakan piranti lunak yang ada akan menghasilkan waktu getar, $T_{c}$.

Tumilar (2011) menyatakan bahwa dalam perhitungan gaya geser dasar seismik menggunakan spektrum respon, maka nilai $T_{c}$ yang diambil tidak perlu diambil lebih besar dari nilai $T_{a}$ (untuk penampang retak), namun tidak lebih kecil dari nilai $C_{u} \cdot T_{a}$ (untuk penampang utuh).

\section{KESIMPULAN DAN SARAN}

Kesimpulan yang dapat diambil dari hasil penelitian ini adalah :

- Persamaan empiris untuk menghitung waktu getar sistem struktur pelat datar belum tersedia di dalam Standar Perencanaan Ketahanan Gempa SNI 1726-2012

- Dalam perencanaan suatu sistem struktur pelat datar yang mempertimbangkan beban gempa, maka perlu diambil suatu persamaan empiris waktu getar yang dapat ditentukan sebagai berikut :

- Untuk kondisi penampang utuh : $T_{a}=$ $0,0022(B)^{\prime \prime} " h_{n}^{1,15}$

- Untuk kondisi penampang retak $: T_{a}=$ $0,0025(B), " ' h_{n}^{1,28}$

Dengan $B$ adalah lebar bangunan dan $h_{n}$ adalah tinggi bangunan, yang dinyatakan dalam satuan meter.

\section{DAFTAR PUSTAKA}

Abdo, M.A. (2012). Modeling of Shear-wall Dominant Symmetrical Flat-Plate Reinforced Concrete Buildings. International Journal of Advanced Structural Engineering. Vol. 4 No. 2

Balkaya, C., Kalkan, E. (2003). Estimation of Fundamental Periods of Shear-wall Dominant Building Structures. Earthquake Engineering Structural Dynamic Journal No. 32. pp. $985-998$

Cinitha, A., Umesha, P.K., Nagesh, R.I. (2012). A Rational Approach for Fundamental Period of Low and Medium Rise Steel Building Frames. International Journal of Modern Engineering Research. Vol. 2. Issue 5. pp. 3340-3346.

SNI-03-1726-2012. (2012), Standar Perencanaan Ketahanan Gempa untuk Struktur Bangunan Gedung dan Non-Gedung. Bandung: Badan Standarisasi Nasional Indonesia.

SNI 03-2847-2002. (2002) Tata Cara Perencanaan Struktur Beton Untuk Bangunan Gedung. Depkimpraswil. Bandung

SNI 2847:2013. (2013). Persyaratan Beton Struktural Untuk Bangunan Gedung. Badan Standardisasi Nasional. Jakarta.

Tumilar, S., 2011, Perancangan Struktur Tahan Gempa Sesuai Konsep SNI Gempa Baru. Jakarta: HAKI (Himpunan Ahli Konstruksi Indonesia)

Wight, J.K, MacGregor, J.G. (2009). Reinforced Concrete Mechanics \& Design. $5^{\text {th }}$ ed. Pearson Prentice Hall. ISBN : 978-0-13207474-2 